\title{
EVALUATION OF THE FABRICABILITY OF ADVANCED IRON ALUMINIDE-CLAD AUSTENITIC STAINLESS STEEL TUBING
}

\author{
W. R. Mohn \\ M. J. Topolski
}

Date Issued: July 1993

Research sponsored by the U.S. Department of Energy, Fossil Energy

Advanced Research and Technology Development Materials Program

Report Prepared by

Babcock \& Wilcox

Research and Development Division

1562 Bceson Street

Alliance, Ohio 44601

under

Subcontract Number 72X-SB775-C

B\&W CRD 1207

for

OAK RIDGE NATIONAL LABORATORY

Oak Ridge, Tennessee 37831

managed by

MARTIN MARIETTA ENERGY SYSTEMS, INC.

for the

U.S. Department of Energy

under Contract No. DE-AC05-84OR21400

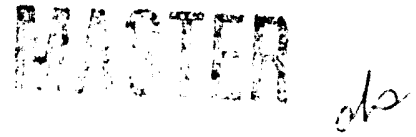




\section{TABLE OF CONTENTS}

Section

Page

EXECUTIVE SUMMARY $\ldots \ldots \ldots \ldots \ldots \ldots \ldots$

INTRODUCTION $\ldots \ldots \ldots \ldots \ldots \ldots \ldots \ldots$

EVALUATION OF COMPATIBILITY $\ldots \ldots \ldots \ldots \ldots$

CLAD TUBE FABRICATION $\ldots \ldots \ldots \ldots \ldots \ldots \ldots \ldots$

EVALUATION AND RESULTS $\ldots \ldots \ldots \ldots \ldots \ldots$

Appendix A. Certification for Iron Aluminide Powder

Appendix B. Certification for 304 Stainless Steel Base Metal

Appendix C. Diagram of Hot Isostatic Pressing of Composite Billets

Appendix D. Diagram of Machined Composite Billet

Appendix E. Certification of Test For Ultrasonic Inspection of Extruded Composite Tubing

Appendix F. Procedure for Etching of Iron Aluminide-Clad 304 Stainless Steel

Appendix G. Distribution List 


\section{LIST OF FIGURES}

Figure

Page

1. Die Assembly for clad specimen fabrication. The $\mathrm{Fe}_{3} \mathrm{Al}$ powder was placed between the $310 \mathrm{SS}, 304 \mathrm{SS}$, $\mathrm{m} 800 \mathrm{H}$, and modified $316(\mathrm{LSS})$ specimens $\ldots \ldots \ldots \ldots \ldots \ldots$

2. Comparison of microstructures showing diffusion zones at interfaces for $\mathrm{Fe}_{3} \mathrm{Al}$-clad substrates, including a) modified 316 (LSS), b) modified $800 \mathrm{H}$, c) standard 310 , and

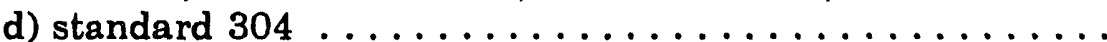

3. Photomacrograph (0.75X) showing cross-sections from (a) the nose and (b) the tail of the clad tube extruded at $2200^{\circ} \mathrm{F}$ and from (c) the nose and (d) the tail of the clad tube extruded at $2000^{\circ} \mathrm{F} \ldots \ldots \ldots \ldots \ldots \ldots \ldots \ldots$

4. Photomicrograph (100X) showing the microstructure and diffusion layers associated with the cladding/substrate interface

5. Photomicrograph (100X) showing the microstructure, diffusion layers, and cracking associated with the cladding/substrate interface

6. Composition profiles for chromium, nickel, and aluminum with respect to the iron aluminide304 SS interface 
Babcock \& Wilcox

a McDermott company

\section{LIST OF TABLISS}

Table

Page

1. Chemical compositions of iron aluminide powder and austenitic stainless steel substrates (wt \%) $\ldots \ldots \ldots \ldots$

2. Chemical compositions of iron aluminide powder and Type 304 austenitic stainless steel substrate (wt \%) 


\section{EVALUATION OF THE FABRICABHLITY OF ADVANCED IRON ALUMINIDE-CLAD AUSTENITIC STAINLESS STEEL TUBING}

W.R. Mohn

M.J. Topolski

\section{EXECUTIVE SUMMARY}

Researchers at Babcock \& Wilcox Alliance Research Center have investigated methods to produce bimetallic tubing consisting of iron aluminide-clad austenitic stainless steel for practical use in fossil fueled energy equipment. In the course of this work, the compatibility of iron aluminide with four candidate austenitic stainless steel substrates was first evaluated using diffusion couples. Based on these results, a combination of iron aluminide and 304 stainless steel was selected for further development. Two composite billets of this combination were then prepared and extruded in separate trials at $2200^{\circ} \mathrm{F}$ and $2000^{\circ} \mathrm{F}$. Both extrusions yielded 2-inch O.D. clad tubes, each approximately 18 feet long. Results of the evaluation show that the tube extruded at $2000^{\circ} \mathrm{F}$ had a sound, integrally bonded clad layer throughout its entire length. However, the tube extruded at $2200^{\circ} \mathrm{F}$ exhibited regions of disbonding between the clad layer and the substrate. In supplement to this work, an assessment of the technical and economic merits of iron aluminide-clad austenitic stainless steel components in power generation systems was conducted by B\&W Fossil Power Division. Future activities should include an investigation of lower extrusion processing temperatures to uptimize the fabrication of high quality ironaluminide clad tubing.

\footnotetext{
Key Words: Tubing, Iron Aluminide, Cladding, Austenitic Stainless Steel, Fabrication, Composite, Interface Bond, Assessment
}

Research sponsored by the U.S. Department of Energy, Fossil Energy AR\&TD Materials Program, DOE/FE AA 151010 0, Work Breakdown Structure Element B\&W-4. 


\subsection{INTRODUCTION}

Results of development work at ORNL and other laboratories have shown that iron aluminide intermetallics exhibit excellent oxidaticn and sulfidation resistance, as well as good resistance to abrasive wear and erosion ${ }^{1}$. Although iron aluminides initially displayed low room temperature ductilities, advanced compositions of these matorials could be heated and easily formed into useful shapes by carefully controlling the thermomechanical processing parameters. The successes in fabricating iron aluminide shapes also suggested the potential application of these materials as protective claddings, particularly for components used at high temperatures in corrosive environments ${ }^{2 \cdot 5}$.

In an earlier research program funded by ORNL under the Fossil Energy Materials Program, the Babcock \& Wilcox Cumpany had conducted research to investigate cladding of advanced austenitic structural materials with high chromium alloys (671 and 690) to potentially enhance resistance to coal ash corrosiun ${ }^{6}$. As a logical extension of this work, a research and development program was initiated with the support of ORNL to evaluate the fabricability of iron aluminide-clad austenitic stainless steel tubing. Clad superheater and reheater tubing could eventually serve to extend the capabilities of fossil fueled energy generation systems to operate $z \mathrm{t}$ higher temperatures.

The objectives of this program have been to develop and to demonstrate a method to produce iron aluminide-slad austenitic stainless steel tubing. To meet those objectives, the compatibility of $\mathrm{Fe}_{3} \mathrm{Al}$ with four different austenitic stainless steels (304, 310, $316 \mathrm{LSS}$, and $\mathrm{m} 800 \mathrm{H}$ ) was first evaluated at elevated temperature using diffusion couples. An experimental processing sequence was then devised and tested in two separate fabrication trials. 


\subsection{EVALUATION OF COMPATIBILITY}

Prior to establishing a preferred process for fabricating clad tubing, the compatibility of $\mathrm{Fe}_{3} \mathrm{Al}$ with the selected austenitic stainless steel substrates first had to be assessed. This was accomplished by producing small specimens of each $\mathrm{Fe}_{3} \mathrm{Al} /$ substrate combination under conditions of time, temperature, and shear deformation simulating those anticipated for full scale clad tube fabrication. Metallographic samples were subsequently prepared to enable examination of the $\mathrm{Fe}_{3} \mathrm{Al} /$ substrate interfaces and surrounding microstructures within the clad specimens.

The chemical compositions of the iron aluminide and the austenitic stainless steels used in this evaluation are shown in Table 1. The iron aluminide was procured as -100 mesh powder from ORNL through an approved vendor. The $\mathrm{m} 800 \mathrm{H}$ and the modified 316 lean stainless steel were retrieved from remaining inventory produced under a previous ORNL program; and the standard 304 and standard 310 stainless steels were obtained from a commercial vendor.

Table 1. Chemical compositions of iron aluminide powder and austenitic stainless steel substrates (wt \%)

\begin{tabular}{||l|c|c|c|c|}
\hline \hline Alloy & $C r$ & $N i$ & $F e$ & $A l$ \\
\hline \hline FegAl (FAS) & 2.11 & - & bal & 14.8 \\
\hline $304 S S$ & $18.0-20.0$ & $8.0-11.0$ & bal & - \\
\hline $310 S S$ & $24.0-26.0$ & $19.0-22.0$ & bal & - \\
\hline LSS & $13.0-15.0$ & $15.0-17.0$ & bal & - \\
\hline m800H & $19.0-21.0$ & $29.0-31.0$ & bal & - \\
\hline
\end{tabular}




\subsection{Experimental Procedure}

The specimens were prepared by hot forging a stacked series (alternate layers) of substrate coupons and -100 mesh iron aluminide powder at $1050^{\circ} \mathrm{C}\left(1922^{\circ} \mathrm{F}\right)$ in an $\mathrm{m} 800 \mathrm{H}$ cylindrical die assembly, Figure 1. This apparatus was designed to consolidate the $\mathrm{Fe}_{3} \mathrm{Al}$ powder and to simulate iron aluminide/substrate interface conditions which would be created during the full scale forward extrusion of a canned, $\mathrm{Fe}_{3} \mathrm{Al}$ powder-encased austenitic stainless steel billet. To remove residual water vapor and adsorbed gasses within the powder/substrate stack, the die assembly was heated to $300^{\circ} \mathrm{C}\left(572^{\circ} \mathrm{F}\right)$ in a vacuum furnace and alternately evacuated (to $10^{-6} \mathrm{Torr}$ ) and backfilled with dry nitrogen for two complete cycles. After bakeout, the clearances between the rams and the cylindrical die were immediately weld sealed; then, the thermocoupled assembly was put into a furnace preheated to $1050^{\circ} \mathrm{C}\left(1922^{\circ} \mathrm{F}\right)$. Thermal equilibrium was attained after 15 minutes, whereupon the assembly was removed from the furnace, immediately positioned on a platen and hot forged with a $4550 \mathrm{Kgf}$ ( $5 \mathrm{ton}$ ) steam driven forging hammer. During the six successive strikes of the forging hammer, the temperature of the die assembly did not fall below $910^{\circ} \mathrm{C}\left(1679^{\circ}\right)$. After forging, the die assembly was allowed to cool to ambient temperature.

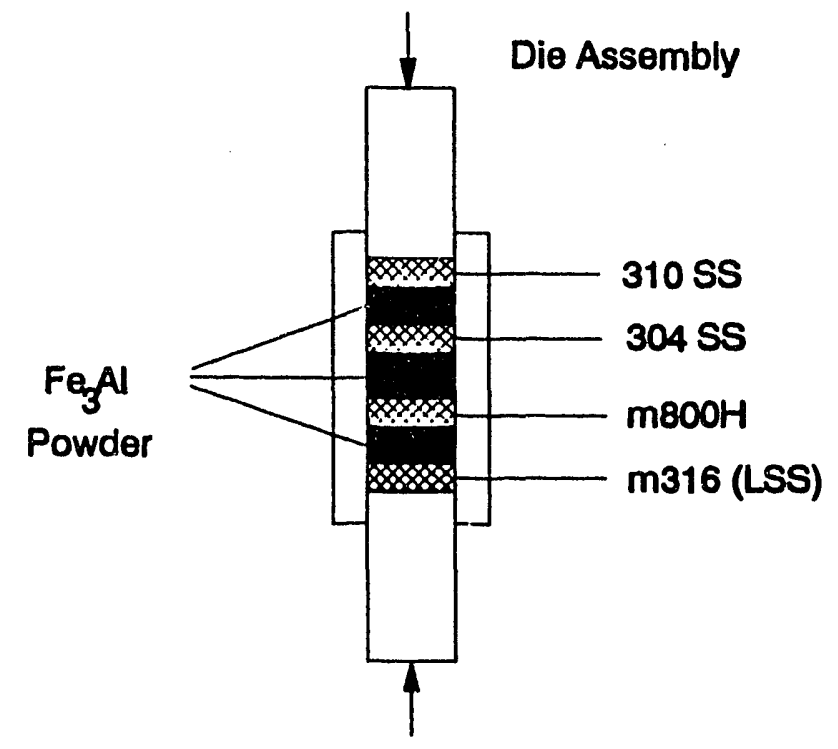

Figure 1. Die Assembly for clad specimen fabrication. The Fe Al powder was placed between the 310SS, 304SS, mo00H, arid modified 310 (LSS) specimens. 


\subsection{Microstructural Evaluation}

The die assembly was sectioned through the diameter along the axial length, and one exposed face was ground, polished and etched (with chromic acid) for microstructural examination. Each of the four $\mathrm{Fe}_{3} \mathrm{Al} /$ substrate interfaces were studied and compared to one another using optical microscopy at various magnifications up to $1000 \mathrm{X}$. The $500 \mathrm{X}$ photomicrographs displayed in Figure 2 show that, although full density was not attained in the iron aluminide layers, consolidation was sufficient to establish the desired metallurgical bond between the iron aluminide and the austenitic stainless steel substrates.

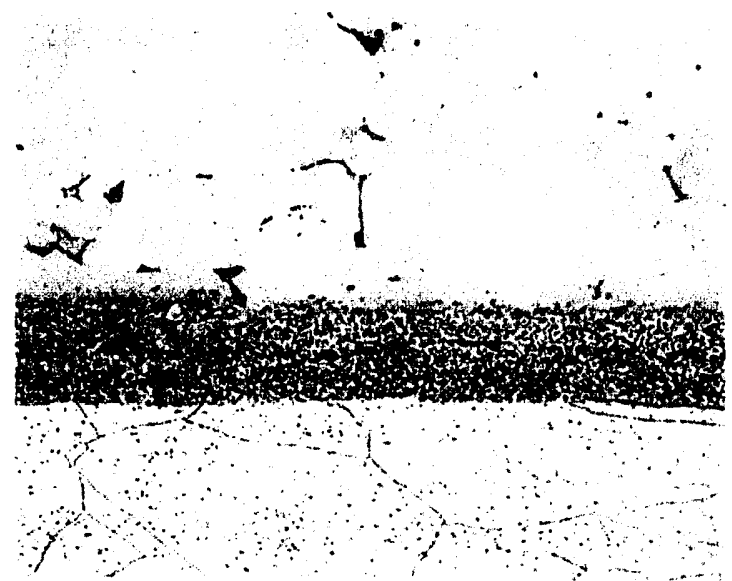

(a)

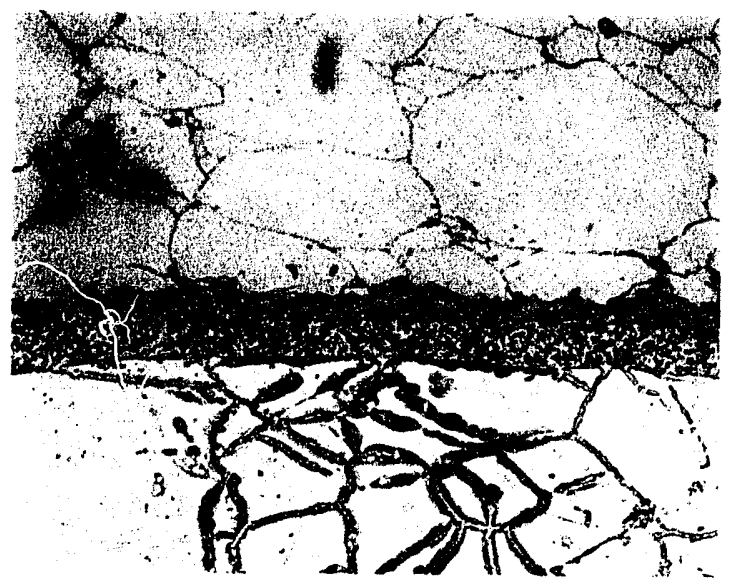

(c)̀̀
$25.4 \mu \mathrm{m}$

$25.4 \mu \mathrm{m}$

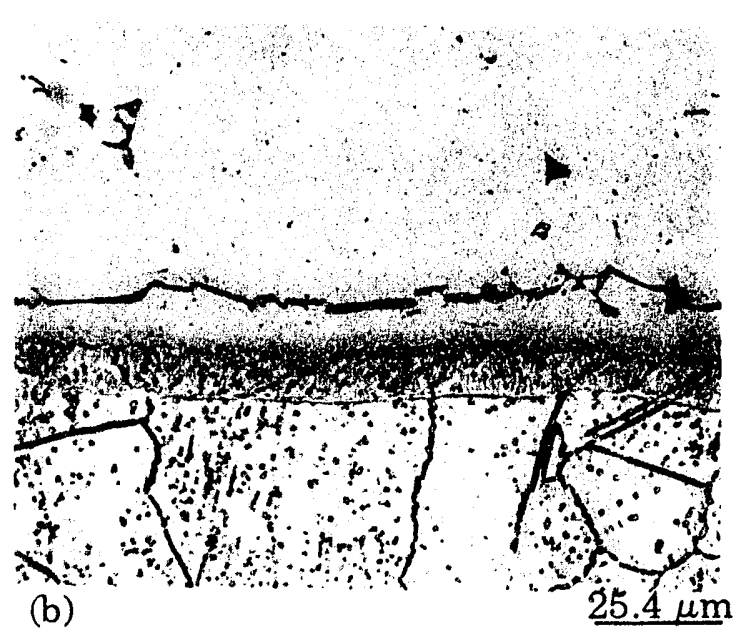

(b)

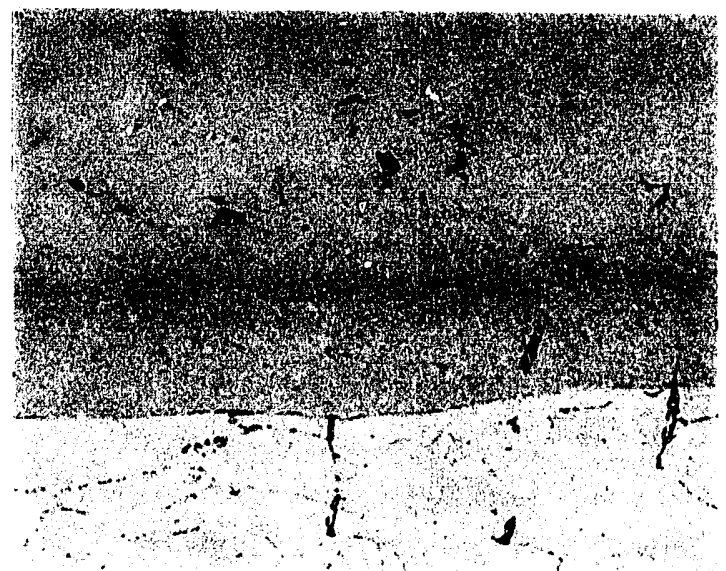

(d)

$25.4 \mu \mathrm{m}$

Figure 2. Comparison of microstructures showing diffusion zones at interfaces for $\mathrm{Fe}_{3} \mathrm{Al}$-clad substrates, including a) modified 316 (LSS), b) modified $800 \mathrm{H}$, c) standard 310, and d) standard 304. 
The principal features of interest in the photomicrographs of Figure 2 are the well defined diffusion zones which extend from the interface into the stainless steel substrate for all four material combinations. Within the boundaries of these distinct layers, having widths ranging from about $13 \mu \mathrm{m}(0.0005 ")$ to about $22 \mu \mathrm{m}(0.0009 ")$, are precipitates which have been analytically determined to be nickel aluminides.

Results showed that the $\mathrm{Fe}_{3} \mathrm{Al} / 304$ austenitic stainless steel combination offered the highest potential for success based on the comparative characteristics of the diffusion layers (including total width, sub-layer widths, precipitation particle content, and cracking) which formed at the interfaces. Selection of this combination, established through joint assessment between ORNL and B\&W, was based on the relatively low content of embrittling nickel aluminides in the diffusion layer and on the absence of microcracking. 


\subsection{CLAD TUBE FABRICATION}

The processing soryence for producing clad tubing was established, in part, on the basis of earlier work conducted at ORNL and at $B \& W^{\gamma \cdot 10}$. The principal components of the processing sequence which incorporate commercial metalworking procedures and equipment is as follows:

* Procurement of Materials ( $\mathrm{Fe}_{3} \mathrm{Al}$ Powder, 304SS)

* Hot Isostatic Pressing to Form Two Composite Billets

* Composite Billet Machining \& Preparation

* Ultrasonic Inspection of Composite Billets

* Hot Forward Extrusion to Form Two Clad Tubes

* Evaluation of $\mathrm{Fe}_{3} \mathrm{Al}$-Clad 304SS Tubes

\subsection{Procurement of Materials}

To produce the composite billets needed for clad tube fabrication, 200 pounds of FAS $\mathrm{Fe}_{3} \mathrm{Al}$ powder (-100 mesh) were procured from an ORNL approved commercial vendor, Appendix A. Annealed 304 stainless steel round stock was purchased from another vendor, Appendix B. The chemical compositions of the FAS iron aluminide powder and the 304 austenitic stainless steel are given in Table 2.

Table 2. Chemical compositions of iron aluminide powder and Type 304 austenitic stainless steel substrate (wt.\%).

\begin{tabular}{||c|c|c|c|c|}
\hline \multicolumn{1}{|c|}{ Alloy } & $C r$ & $N i$ & Fe & $A l$ \\
\hline \hline FegAl (FAS) & 2.2 & - & bal & 15.0 \\
\hline 304SS & 18.50 & 8.22 & bal & - \\
\hline
\end{tabular}




\subsection{Hot Isostatic Pressing of Composite Billets}

HIP processing was incorporated into the fabrication sequence to simultaneously effect full powder consolidation and to ensure complete encasement and bonding of the $\mathrm{Fe}_{3} \mathrm{Al}$ to the machined 304SS hollow cores. The $\mathrm{Fe}_{3} \mathrm{Al}$ powder/304SS assemblies were weld sealed in carbon steel jackets, evacuated, degassed, and HIP'ed at $2065^{\circ} \mathrm{F} / 14.5 \mathrm{ksi}$ (with argon gas) for 4 hours, Appendix C.

\subsection{Machining and Preparation of Composite Billets}

The HIP'ed assemblies were initially rough-machined to remove the carbon steel enclosures. Each of the 6-inch diameter billets was further machined to properly size the central core, configure the proper nose geometry, and dress the $\mathrm{Fe}_{3}, \mathrm{Al}$ exterior surfaces in preparation for hot forward extrusion, Appendix D.

\subsection{Ultrasonic Inspection of Composite Billets}

The machined composite billets were ultrasonically inspected to confirm the integrity of the bond between the $\mathrm{Fe}_{3} \mathrm{Al}$ encasement and the 304SS substrate. Results of the inspection confirmed integral bonding throughout the lengths of both billets.

\subsection{Hot Forward Extrusion of Clad Tubing}

Extrusion process parameters were selected by B\&W based on information obtained from the technical literature, recommendations by ORNL, and practical production experience of the extrusion press operator. During the first extrusion trial, the billet was induction heated to $2200^{\circ} \mathrm{F}$, lubricated with powdered silica, and extruded on a 4500 ton hydraulic press, producing an 18-foot long clad tube. In the next trial, the second billet was extruded at a lower temperature of $2000^{\circ} \mathrm{F}$, again successfully producing an 18-foot long clad tube.

Both tubes were "natural" air cooled (rather than water quenched) to minimize the generation of stresses which could cause tube distortion or clad layer cracking. After air cooling to room temperature, the two iron aluminide-clad 304SS tubes were carefully packgged, boxed and shipped for subsequent evaluation. 


\subsection{EVALUATION AND RESULTS}

\subsection{Visual Inspection}

Both extruded $\mathrm{Fe}_{3} \mathrm{Al}$-clad 304SS tubes were visually ins-pected to assess their overall condition. The tubes were circular, without eccentricity, with a predominantly uniform wall thickness. Measurements of straightness showed a slight, nonuniform bow which skewed randomly from about 1/8" - 1/4" per linear foot. Exterior surfaces were moderately smooth and were still coated with remnants of the silica lubricant used during hot extrusiol. There were no observable surface defects or other anomalies on either of the tubes.

\subsection{Ultrasonic Inspection}

The clad tubes were ultrasonically inspected at one-foot intervals along their length. At each inspection interval, measurements were taken at four radial positions $\left(0^{\circ}\right.$, $90^{\circ}, 180^{\circ}$, and $270^{\circ}$ ). Constant (sound) velocity was assumed through both the cladding and substrate materials. Results showed that the tube extruded at $2000^{\circ} \mathrm{F}$ had no indication of disbonding between the cladding and substrate. However, the tube extruded at $2200^{\circ} \mathrm{F}$ exhibited regions of peripheral disbonding along its 18-foot length, Appendix E.

\subsection{Metallographic Examination}

Cross-sectional specimens were taken from the nose, center, and tail regions of each extruded tube for microstructural examination. Dimensional measurements were also taken on the specimens to confirm circularity, determine average outside and inside diameters, establish typical wall thickness, and assess nominal clad layer thickness. The photomacrograph of the nose and tail specimens, Figure 3, shows that both tubes were circular with predominantly uniiorm wall thicknesses. However, the clad layer thicknesses in the region of the nose for both tubes showed noticeable variations, particularly for the tube extruded at $2200^{\circ} \mathrm{F}$ (Figure 3a). 


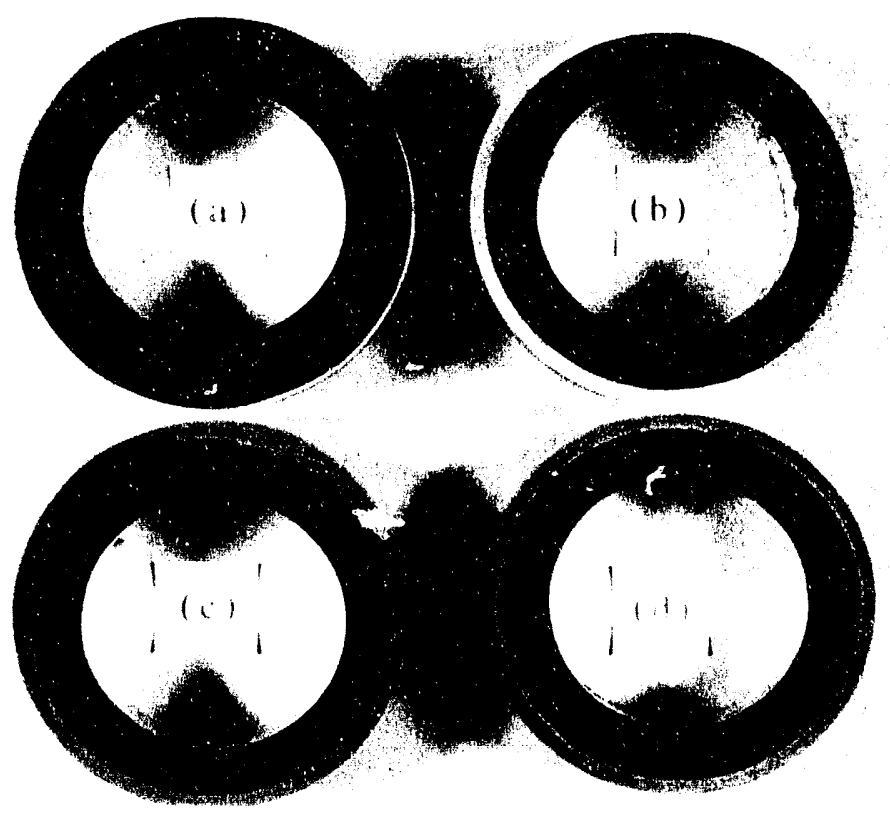

Figure 3. Photomacrograph $(0.75 X)$ showing cross-sections from (a) the nose and (b) the tail of the clad tube extruded at $2200^{\circ} \mathrm{F}$ and from (c) the nose and (d) the tail of the clad tube extruded at $2000^{\circ} \mathrm{F}$.

The microstructures of the cladding/substrate interfaces were next examined to characterize bonding. Etching of the metallic specimens was conducted in accordance with the procedure given in Appendix F. Figure 4 displays a photomicrograph showing the integral metallurgical bond (with associated diffusion layers) that are typical for the nose, center, and tail regions of the tube extruded at $2000^{\circ} \mathrm{F}$. In contrast, Figure 5 displays a photomicrograph showing the cracking and disbonding typically observed throughout the tube extruded at $2200^{\circ} \mathrm{F}$. 


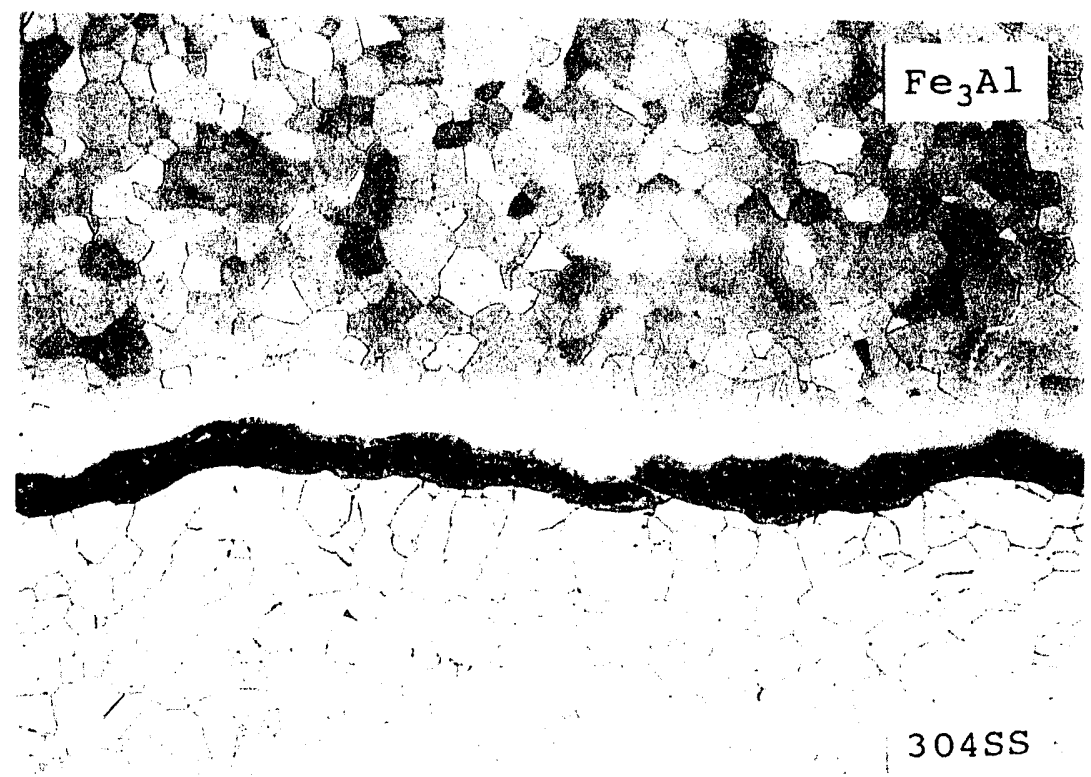

Figure 4. Photomicrograph (100X) showing the microstructure and diffusion layers associated with the cladding/substrate interface.

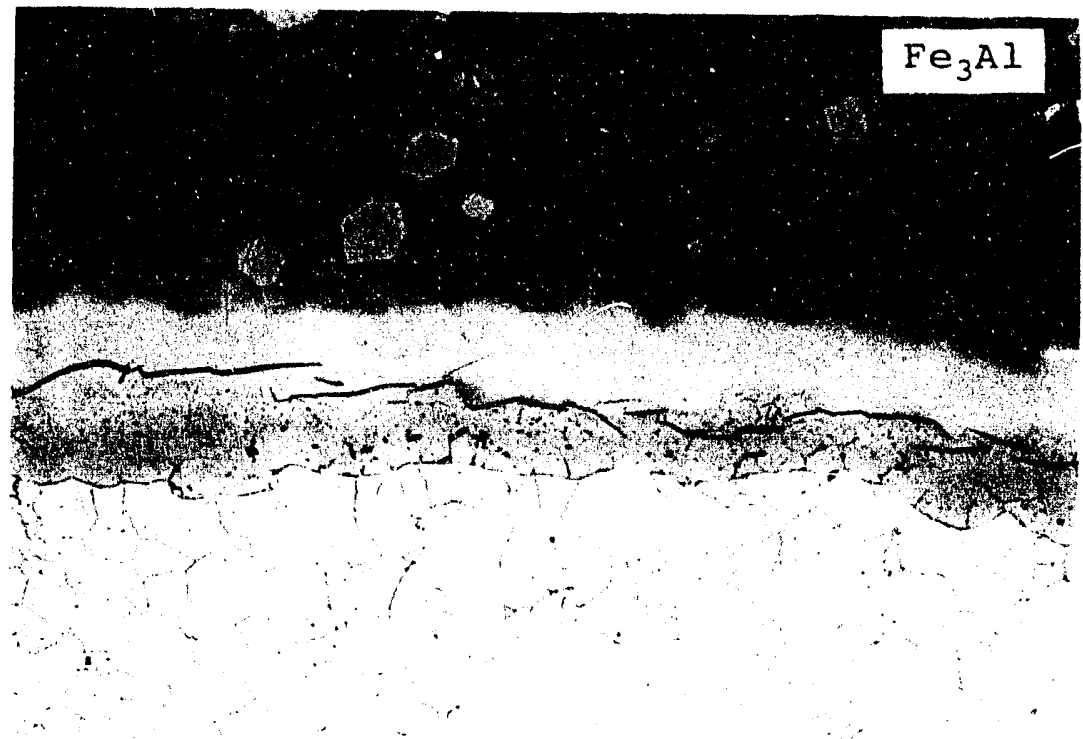

Figure 5. Photomicrograph (100X) showing the microstructure, diffusion layers, and cracking associated with the cladding/substrate interface. 


\subsection{Composition Profiling}

Composition (step) profiles for chromium, nickel, and aluminum were determined across the diffusion layers using electron probe microanalysis. Figure 6 illustrates the variation in concentrations for selected elements, in relation to the $\mathrm{Fe}_{3} \mathrm{Al} / 304 \mathrm{SS}$ interface, resulting from interdiffusion. Location " $\mathrm{A}$ " denotes the center of the dark diffusion zone within the 304SS substrate; location "B" denotes the center of the light diffusion zone within the iron aluminide cladding.

\section{Composition Profiles}

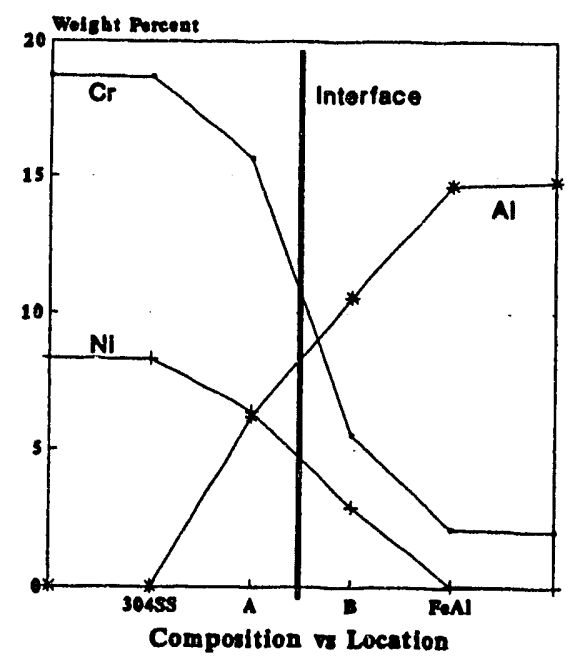

Figure 6. Composition profiles for chromium, nickel, and aluminum with respect to the iron aluminide-304 SS interface. 


\subsection{TECHNICAL AND ECONOMIC ASSESSMENT}

The technical and economic merits of $\mathrm{Fe}_{3} \mathrm{Al}$-clad austenitic stainless steels were examined by the Babcock \& Wilcox Fossil Power Division (FPD) and assessed with respect to potential power boiler applications. The assessment was based on the understanding that the developed clad tubing would have the necessary properties and characteristics to allow its use at about $1100^{\circ} \mathrm{F}$ to $1300^{\circ} \mathrm{F}$ for extended service. A summary of the FPD observations are given below.

* To be commercially feasible, $\mathrm{Fe}_{3} \mathrm{Al}$-clad austenitic stainless steel tubing must be formable, capable of small bend radii. Superheater and reheater sections currently have bend radii as small as two tube diameters. Bends with $R / D$ ratios of 3 or 4 are common. If such bends cannot be made cold (room temperature), then the feasibility of hot bending, as well as the resultant effects on clad tube properties, must be determined.

* The cost of clad tubing, due to a more complex production sequence, will be greater than that of monolithic alloy tubing. Accordingly, the gains in extended life and performance provided by the clad tubing will have to justify the greater initial cost.

* For consideration as superheater and reheater applications, $\mathrm{Fe}_{3} \mathrm{Al}$-clad tubing must be evaluated for resistance to coal ash and oil ash corrosion, as well as for resistance to other types of corrosion and erosive degradation.

* Practical use of $\mathrm{Fe}_{3} \mathrm{Al}$-clad tubes will require effective methods for fusion welding and for protecting all welds (during service) which are required for assembly, attachment, and installation.

* Since commercial use of $\mathrm{Fe}_{3} \mathrm{Al}$-clad austenitic stainless steel tubes will always be sensitive to cost, they will first be utilized only in the hottest parts of superheaters. These initial applications will provide a relatively small market compared to the less expensive alloy tubing.

* Potential applications for fully developed $\mathrm{Fe}_{3} \mathrm{Al}$-clad tubing include superheaters for syngas coolers, conventional utility boilers, and advanced boiler systems where creep and coal ash corrosion are especially problematic. 


\subsection{CONCLUSIONS AND RECOMMENDATIONS}

Separate fabrication trials were conducted in this program to produce two $\mathrm{Fe}_{3} \mathrm{Al}$ clad 304 austenitic stainless steel tubes. These unique bimetallic tubes were initially characterized through visual and ultrasonic inspections. They were subsequently evaluated through microstructural examination and electron probe microanalysis. Both of the 2-inch OD tubes were approximately 18 feet long with a typical wall thickness of 0.375 inch, including a nominal clad layer thickness of 0.1 -inch. The tube that was extruded at $2000^{\circ} \mathrm{F}$ had an integral, metallurgically bonded clad layer throughout its entire length. The tube extruded at $2200^{\circ} \mathrm{F}$ exhibited multiple regions of clad layer/substrate interface cracking and disbonding.

The results of this work demonstrate that $\mathrm{Fe}_{3} \mathrm{Al}$-clad 304 austenitic stainless steel tubing can be successfully fabricated using the devised processing sequence. The results also indicate the importance of proper temperature selection and control during processing to produce good quality bimetallic tubing. Additional work is recommended to investigate potential benefits of lower extrusion temperatures and to optimize other associated processing parameters. It is also recommended that development trials be conducted to adapt the processing sequence to successfully fabricate $\mathrm{Fe}_{3} \mathrm{Al}$-clad tubing using other austenitic stainless steel substrates.
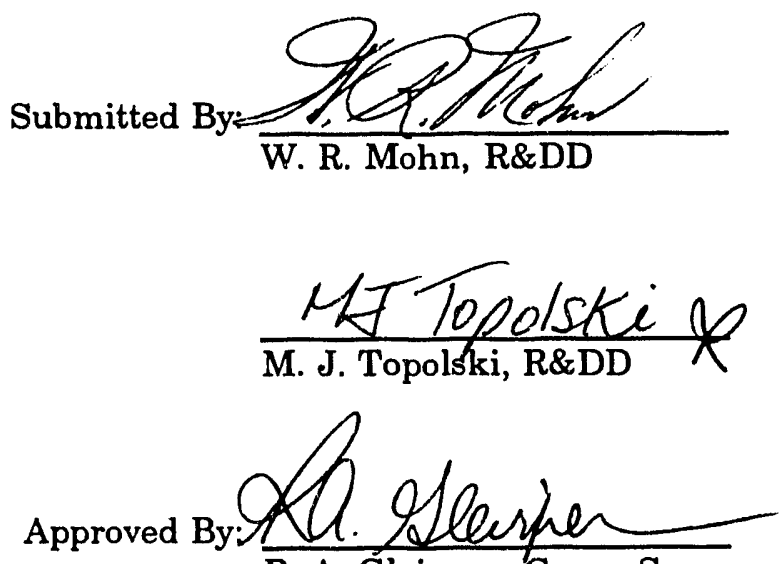

R. A. Gleixner, Group Supv. Met. \& Mfg. Tech. Section

Attach. 


\subsection{ACKNOWLEDGMENTS}

Funding of this work was administered by ORNL under the Fossil Energy Materials Program. Special thanks are due to Ms. Nancy C. Cole, Dr. Robert W.

Swindeman, Dr. Vinod Sikka, all of ORNL, who provided helpful consultation on critical technical issues. The concerted efforts of participants from B\&W's Fossil Power Division, Crucible Compaction Metals, Al Tech Specialty Steel Corporation, and AMETEK Specialty Metal Products Division, who collectively helped to make this project a success, are greatly appreciated. 


\subsection{REFERENCES}

1. C.G. McKamey, "Development of Iron Aluminides," ORNL/FMP-90/1, August 1990.

2. V.K. Sikka, C.G. McKamey, C.R. Howell, and R.H. Baldwin, "Fabrication and Mechanical Properties of $\mathrm{Fe}_{3} \mathrm{Al}$-Based Aluminides," ORNL/TM-11465, March 1990.

3. R.W. Swindeman, P.J. Maziasz, E. Bolling, and J.F. King, "Evaluation of Advanced Austenitic Alloys Relative to Alloy Design Criteria for Steam Service: Part 1 - Lean Stainless Steels," ORNL-6629/P1, May 1990.

4. R.W. Swindeman and P.J. Maziasz, "Evaluation of Advanced Austenitic Alloys Relative to Alloy Design Criteria for Steam Service: Part 2 - 20 to $30 \%$ Chromium Alloys," ORNL-6629/P2, June 1991.

5. R.W. Swindeman, "The Potential of Modified Type 310 Stainless Steel for Advanced Fossil Energy Applications," ORNL/TM-12057, April 1992.

6. M.J. Topolski and H.A. Domian, "Evaluation of the Fabricability of Advanced Austenitic Tubing," ORNL/FMP-90/1, August 1990.

7. W.R. Mohn and M.J. Topolski, "Evaluation of the Fabricability of Advanced Iron Aluminide-Clad Austenitic Stainless Steel Tubing," ORNL/FMP-92/1, July 1992.

8. V.K. Sikka and J.R. Weir, "IRON ALUMINIDES: Properties and Progress in the Development of a Family of Alloys Based on the Intermetallic Compound $\mathrm{Fe}_{3} \mathrm{Al}$," ORNL/Contract DE-AC05-840R21400 with the U.S. Department of Energy, 1990.

9. V.K. Sikka, C.G. McKamey, C.R. Howell, and R.H. Baldwin, "Properties of Large Heats of $\mathrm{Fe}_{3} \mathrm{Al}$-Based Alloys," ORNL/TM-11796, March 1991.

10. C.G. McKamey, C.T. Liu, S.A. David, J.A. Horton, D.H. Pierce, and J.J. Campbell, "Development of Iron Aluminides for Coal Conversion Systems," ORNL/TM-10793, July 1988. 


\title{
Appendix A
}

\author{
Certification For \\ Iron Aluminide Powder
}


(412) 225-8400

PROCESS/QUALITY CONTROL DATA SHEET

\begin{tabular}{|c|c|c|c|}
\hline CUSTOMER: & Batcoct: \& lilcox & $\begin{array}{l}\text { PRODUCT: FAY }(-100) \\
\text { LOT \# : } 195392\end{array}$ & $\begin{array}{l}\text { DATE: } \quad 09 / 16 / 92 \\
\text { PO\#: } 03454 \mathrm{~TB} \\
\text { QUANTITY: } 200 \text { lkS }\end{array}$ \\
\hline
\end{tabular}

\section{CHEMICAL COMPOSITION}

(Weight \%)

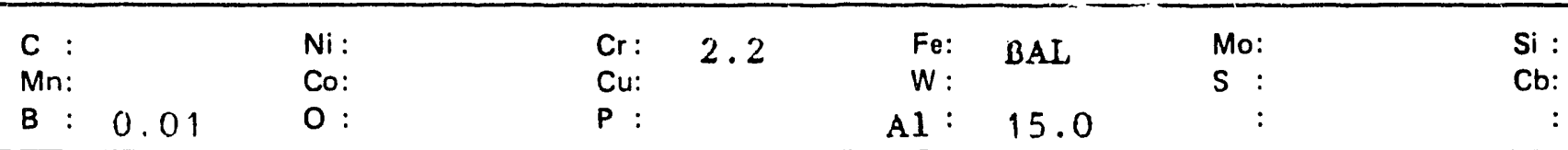

POWDER PHYSICAL PROPERTIES (Size Distribution)

$S$ STANDAKI

ESH SIZE

PERCENT

$+60$

$+100$

$+140$

$+200$

$+270$

$+325$

$-325$
Trace

7.0

19.7

19.7

17.0

6.4

30.2
APPARENT DENSITY: $\quad 3.78 \mathrm{~g} / \mathrm{CC}$

FLOW: No Flow

OTHER:

COMPACTING PROPERTIES

\begin{tabular}{|l|c|c|c|c|c|c|}
$\begin{array}{l}\text { Compact } \\
\text { Pres (tsi) }\end{array}$ & $\begin{array}{c}\text { Green } \\
\text { Dens (g/cc) }\end{array}$ & $\begin{array}{c}\text { Green } \\
\text { Str (psi) }\end{array}$ & $\begin{array}{c}\text { Sinter } \\
\text { Dens (g/cc) }\end{array}$ & $\begin{array}{c}\text { Trans Break } \\
\text { Str (psi) }\end{array}$ & $\begin{array}{c}\text { Dim Change } \\
\text { (\% die size) }\end{array}$ \\
& & & & &
\end{tabular}

LUBRICANT:

SINTERING CONDITIONS:

NOTES AND OTHER DATA:

(1)




\section{Appendix B}

\section{Certification For 304 Stainless Steel Base Metal}


Nov 24,92 14:10 CRUCIBLE COMPACTION Oakdale, PA 412-788-4240

P. 02

Baltimore

BPDCIALTY BTDELO

COMPORATION

a OUDSIDIARY OP ARMCO INC, $\bar{F}$

CERTIFICATION

\begin{tabular}{l|l} 
จा4 70 & 1594
\end{tabular}

a.". "y 4

4his.

TROSNO.

- Covit. 7.14a1tes

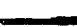

DOSEYH T' FIYEFEON \& EIN INC

NETTER WAREHOUSE

16TH \& ROCINWELLL. ETE

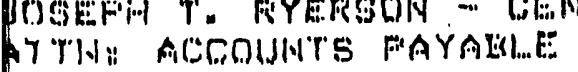

- $0 \cos \operatorname{sgnas}$

CHXC:AC"D

II

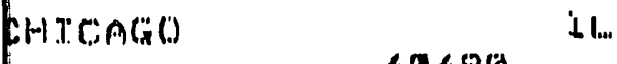

GQGQG

$6 \operatorname{son} 65$

PEODOCTRUNBEER

TESTLIID

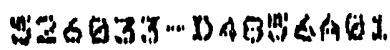

2047

1ABSGABS:

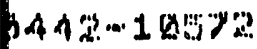

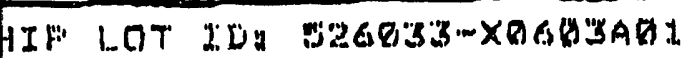

MET LOT NOW: DABWIGA

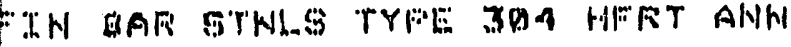

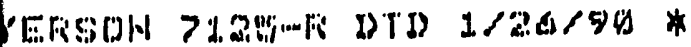

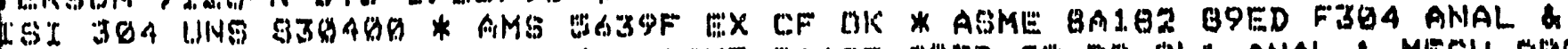

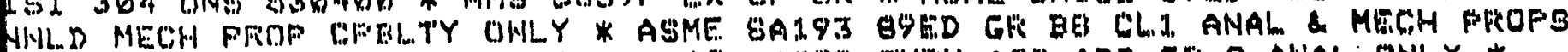

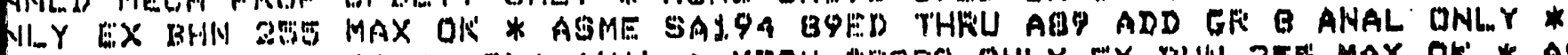

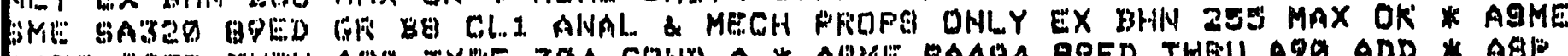

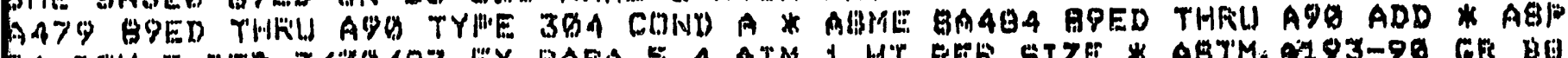

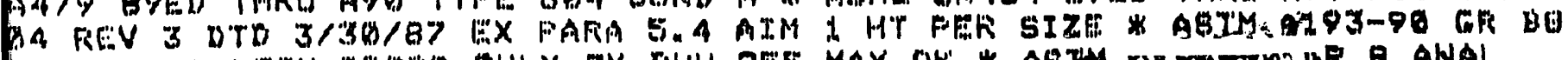

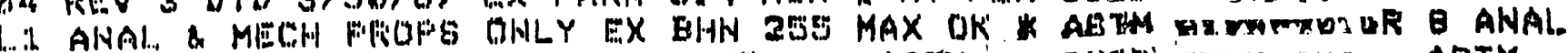

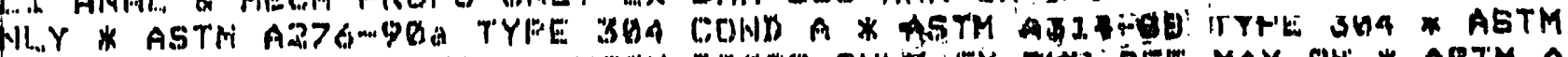

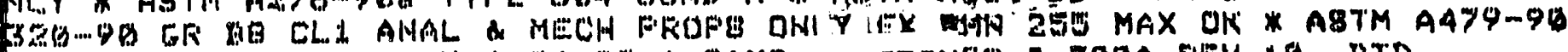

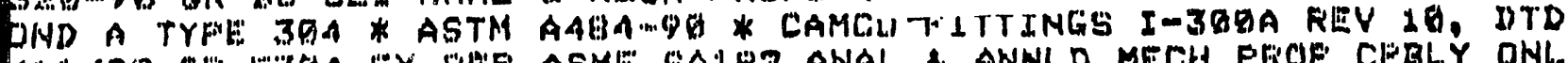

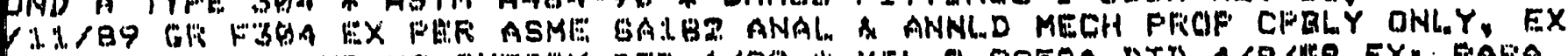

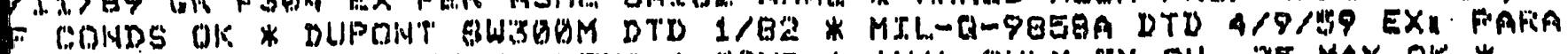

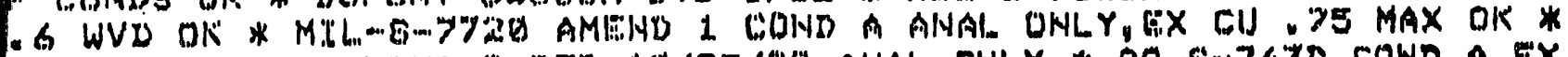

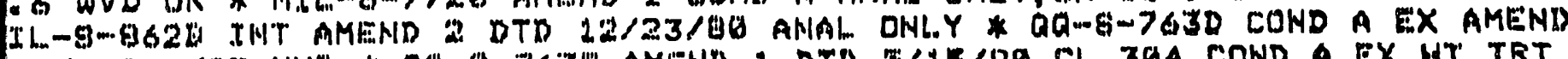

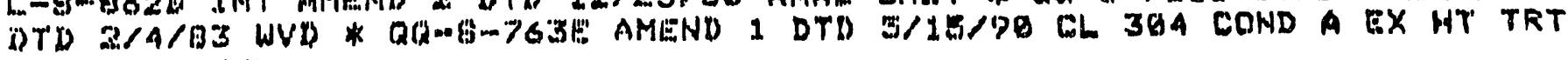

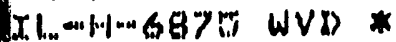

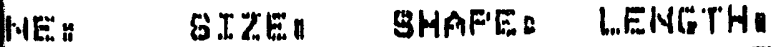

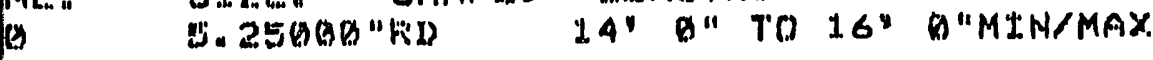

WEI GHTI

I, 643

FF: ANALE FRODUCT ANAL.YYGS

C: 0.07\% MHE H. BQS

HEET NOA 526033

IN'L MOD

A. $3 \sin$

P:

(H. 028 5: 0.024

CU: Q.3DQ COI O.15O

PLE AMAL REELINI.,AFE

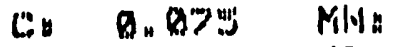

(⿻). 700

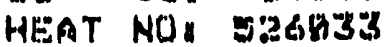

MT: $=21$ MO:

Q. 36 30

$\mathrm{Pl}$

O. Q2." 310.024

CU: O. 20 CBA 0.040

S.5. 0.548

CFI 10.50

Ni B. D61

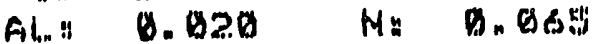

TH:

Q. 1828

$V_{1}$

0.060

SII A.S7\% CIR $2 B .29$

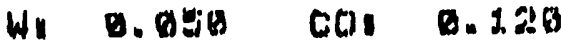

SHTW TEST: ANINIEAL.

B HIEUNS: 278.

HOURSA $\theta$

DFFSE'T XI O. 20

* EIL 2" OR EON 64.

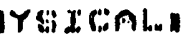

CE AVEI 3.

HTLE 22-925369

[S HRDNSS $(P / F)$ * $O K$

MINE⿱ 30.

UTS KSII BGn'

$X$ RED OF AREAS 74.24

TEMPF 19 W"

QI.TENCHI WATHE

.2X FI.D ETK KSII 41.6

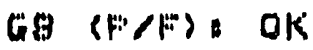

MACPO (F/F) I OK:

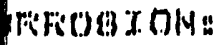

CAFBB/OX (P/F) OK/OI

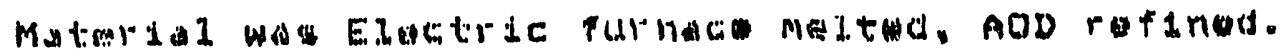


Nov 24.92 14:09 CRUCIBLE COMPACTION Oakdale, PA 412-788-4240

P. 01

BALTIMORE

BPLCIALTY BTEELS

COPPORATION

$\because$ a OULADIARY OR AMMDO INC. $\bar{T}$

- Certification

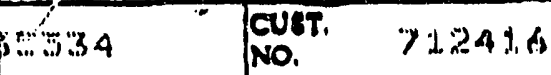

MeL TO

1584

JUEEPH T FYEFSON \& EON IMS

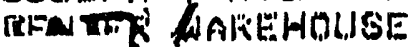

WT 2 ROCKWE:LL, ETE

T"W" ACCOUNITS FAYAENI. F

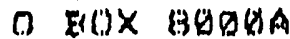

COHICIAGO

IL

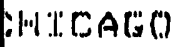

6060

$x_{1} \ldots$

G)

TRObLCT NORi:Li:

44 II) - 2 65972 ratritorito

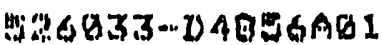

कALTOWDITO

20247

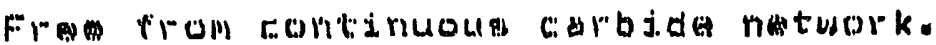

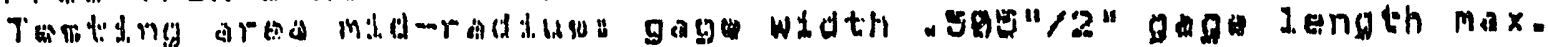

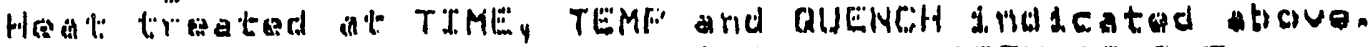

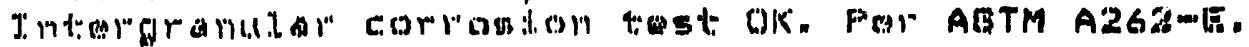

Mas: $r^{\circ} 0$ etch tom

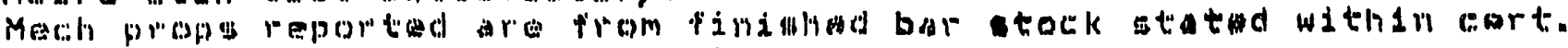

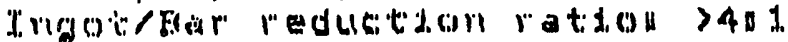

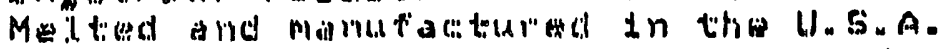

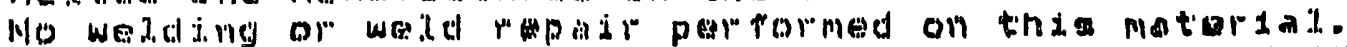

LES

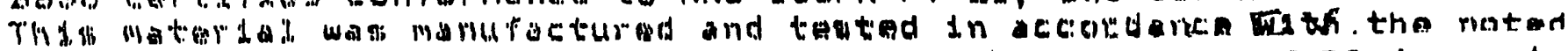

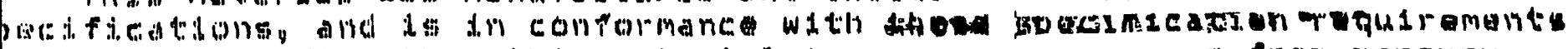

fis

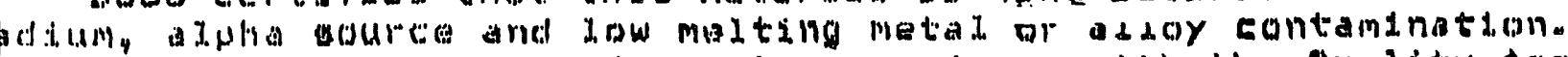

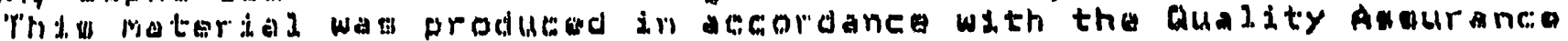

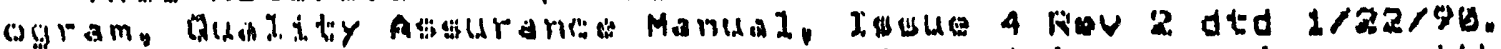

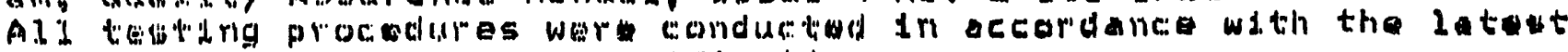

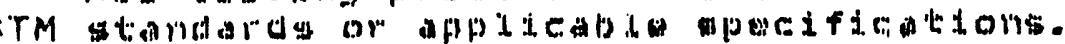

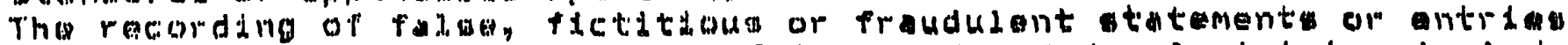

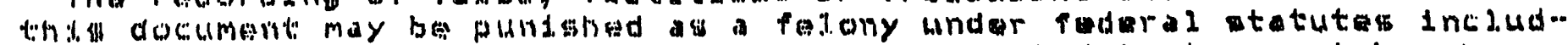

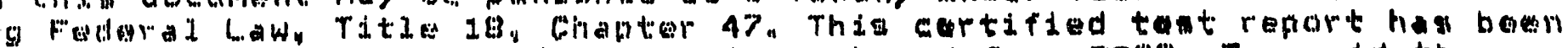
1.

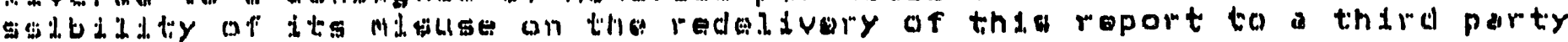

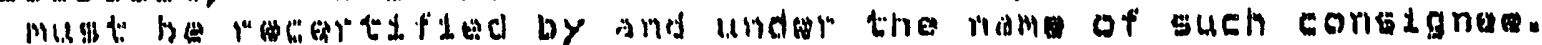

The cillemicil andly

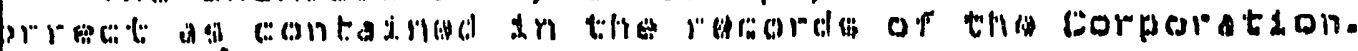

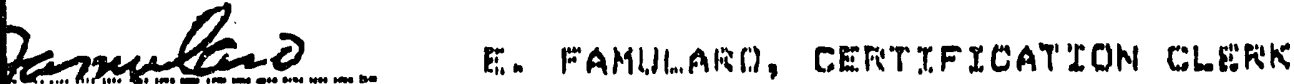

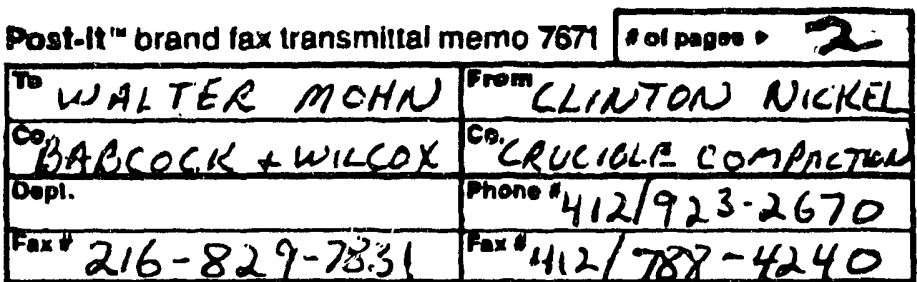




\section{Appendix C}

\section{Diagram Of Hot Isostatic Pressing Of Composite Billets}




\section{HIP Consolidation}

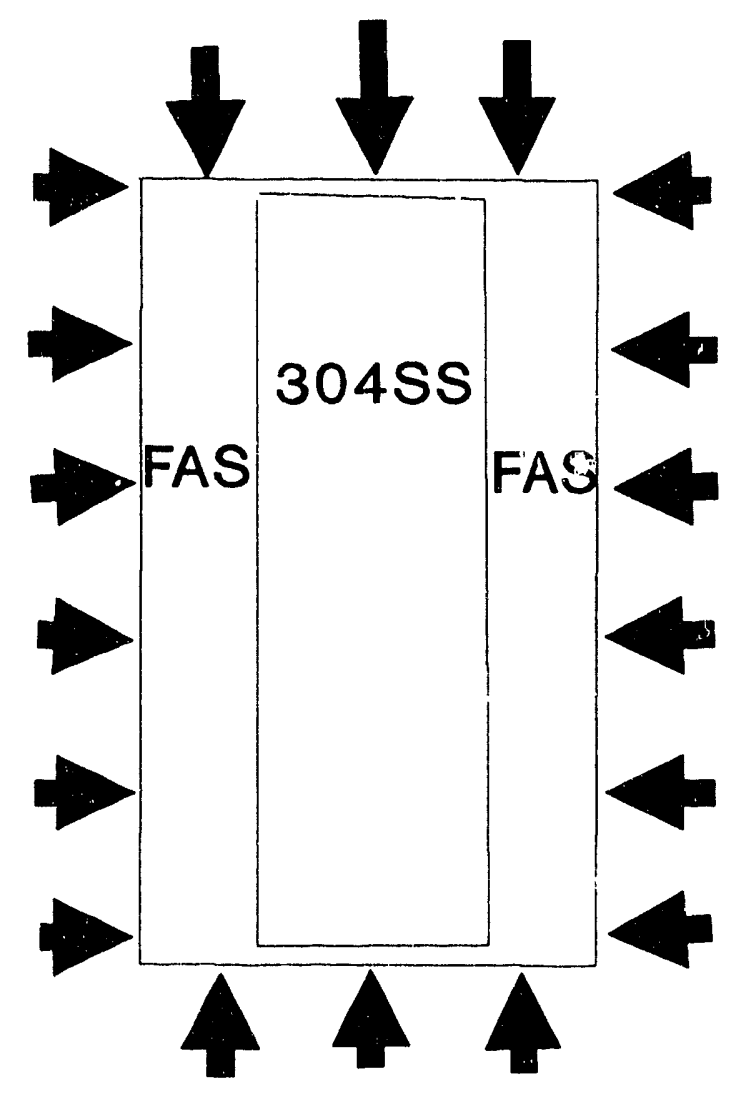

2065F/14.5 ksi (argon)/4 hrs 


\section{Appendix D}

Diagram Of Machined Composite Billet 
Hybrid Billet

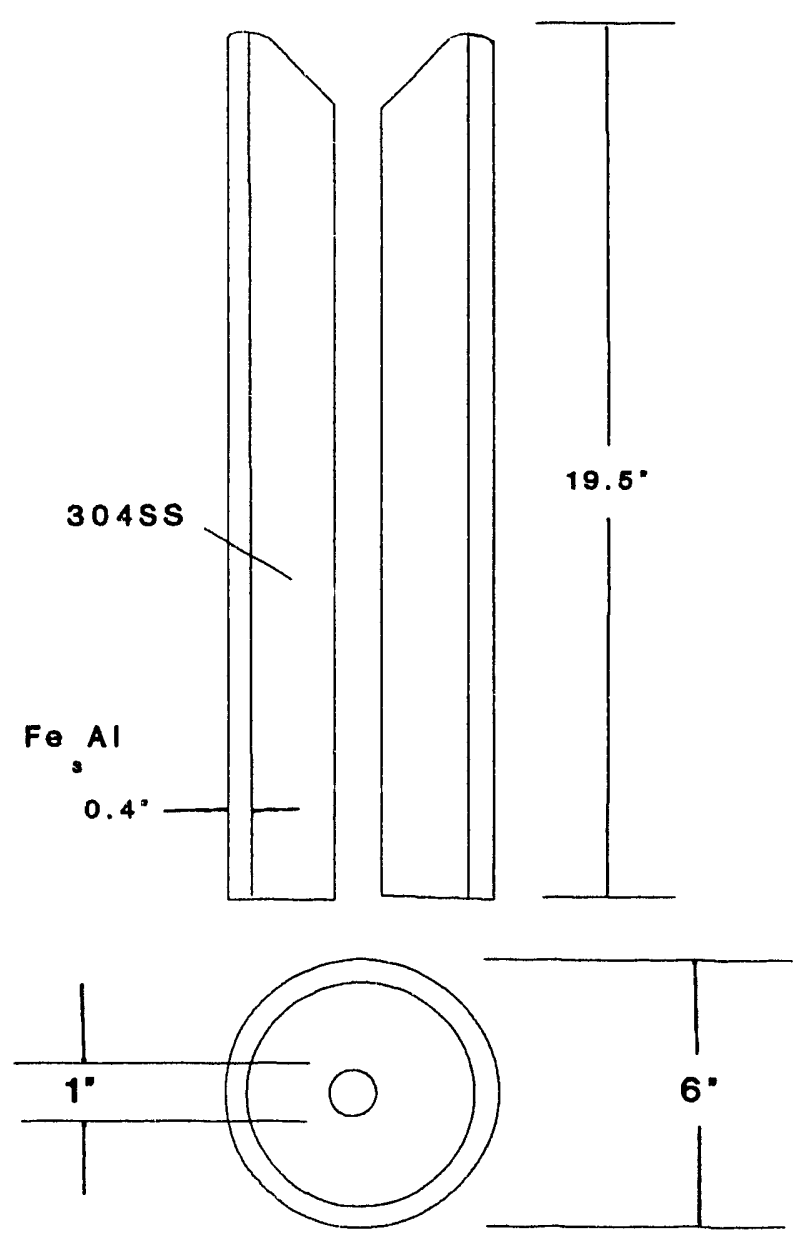




\title{
Appendix E
}

\author{
Certification Of Test For \\ Ultrasonic Inspection Of \\ Extruded Composite 'Tubing
}


Customer

BABCOCK \& WILCOX CO.

CERTIFICATE OF TEST

Page 1 of 2

Job Order No.: 10020 A I CCMD Report No. 2468

Cust. Part No.

$\mathrm{N} / \mathrm{A}$

Cust. Dwg. No./ Rev. I

Specification No.

B\&W TO SPECIFY HIP $P$

P.O. Date

4-AUG-1992

Item No.1 Pieces । Weight

Product Description

1

21

304 Stainless Steel Tubing

Chemical Analysis of Fe-Al Lot 094392 (Weight Percent)

Al
15.0

2.2

OD

I Master Blend No. 095392

HIP Parameters: $2060 \pm 20^{\circ} \mathrm{F}$ o $14500 \pm 500$ psi. for $4 \mathrm{Hr}$.

HIP and machined dimensions.

$\begin{array}{ccccccc}\text { S/N } & \text { Length } & \text { OD } & \text { ID } & \begin{array}{l}\text { Nose Chamfer } \\ 40^{\circ}\end{array} & \text { Nose radius } \\ 123748 & 18.860^{\prime \prime} & 5.890^{\prime \prime} & 1.375^{\prime \prime} / 1.384 " & 40^{\circ} & 1.500^{\prime \prime} & 1 \text {. } \\ 123749 & 18.863^{\prime \prime} & 5.890^{\prime \prime} & 1.381^{\prime \prime} / 1.384^{\prime \prime} & 40^{\circ} & 1.440^{\prime \prime} & \text { Ok }\end{array}$

Aproximate HIP and machined clad thickness measured by UT.

Serial Number 123748

$\begin{array}{rrrrr}\text { loc. } & 0^{\circ} & 90^{\circ} & 180^{\circ} & 270^{\circ} \\ 2 " 1 & .396 & .402 & .396 & .400 \\ 4 " & .395 & .402 & .406 & .403 \\ 6 " & .400 & .402 & .406 & .399 \\ 8 " & .416 & .396 & .402 & .399 \\ 10^{\prime \prime} & .400 & .397 & .396 & .400 \\ 12 " & .415 & .396 & .403 & .400 \\ 14 " & .416 & .397 & .396 & .401 \\ 16 " & .400 & .395 & .401 & .400\end{array}$

Serial Number 123749

loc. $0^{\circ} 90^{\circ}$

$\begin{array}{ll}2^{\prime \prime} & .396 \\ 61 " & .406\end{array}$

6" . .395

.395

$180^{\circ}$

$270^{\circ}$

.407

.395

$\mathrm{Fe}$

Bal.

with Fe-Al. 
Page 2 of 2

Job Order No.: 10020 A CCMD Report No. 2468

\section{CERTIFICATE OF TEST CONTINUED}

UT Dimensional Evaluation: Constant velocity through both materials assumed. Serial Number 123749.

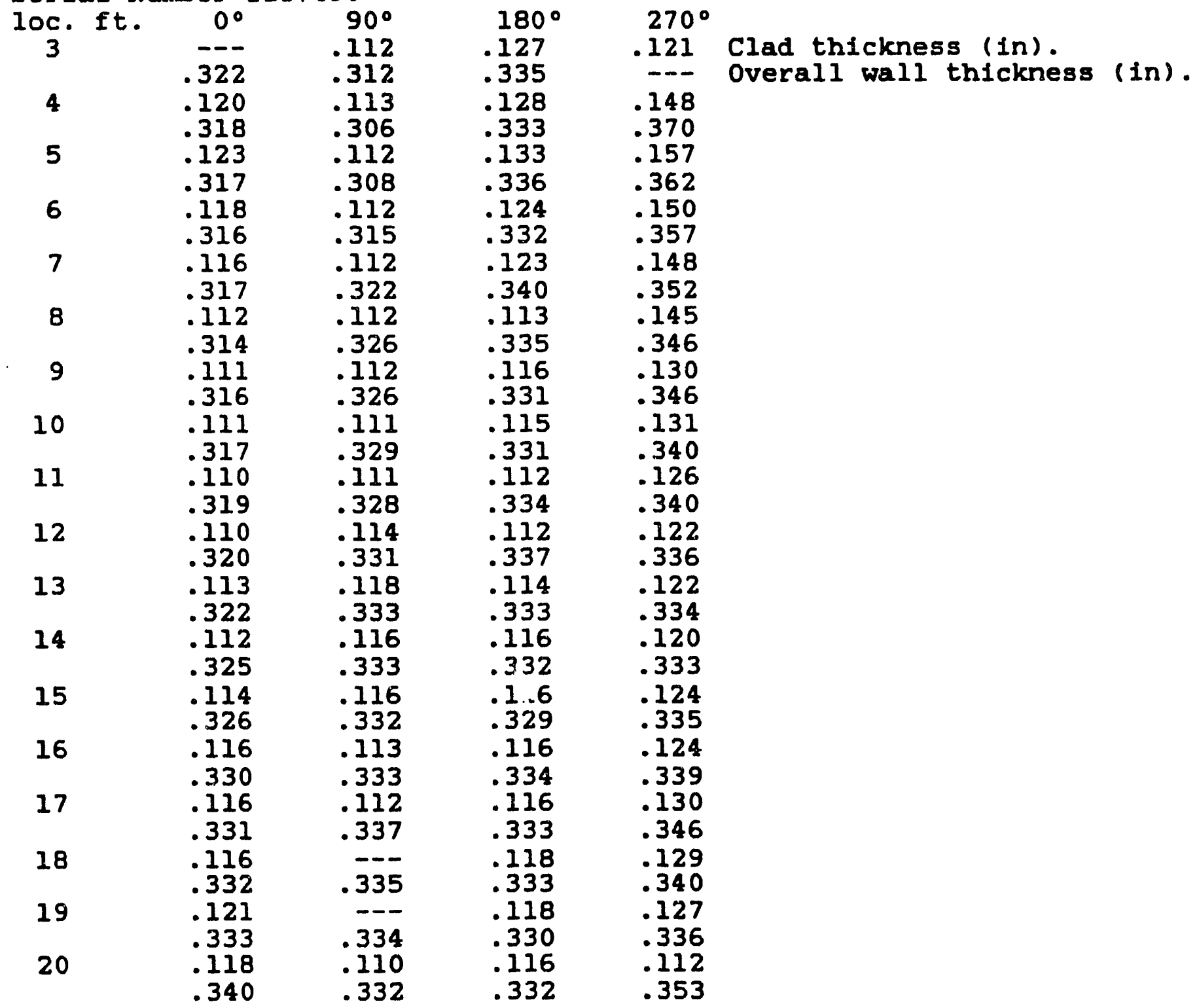

UT dimensional not performed on $S / N$ 123748, disbond noted.

See attached sketch showing post extrusion cutting. 

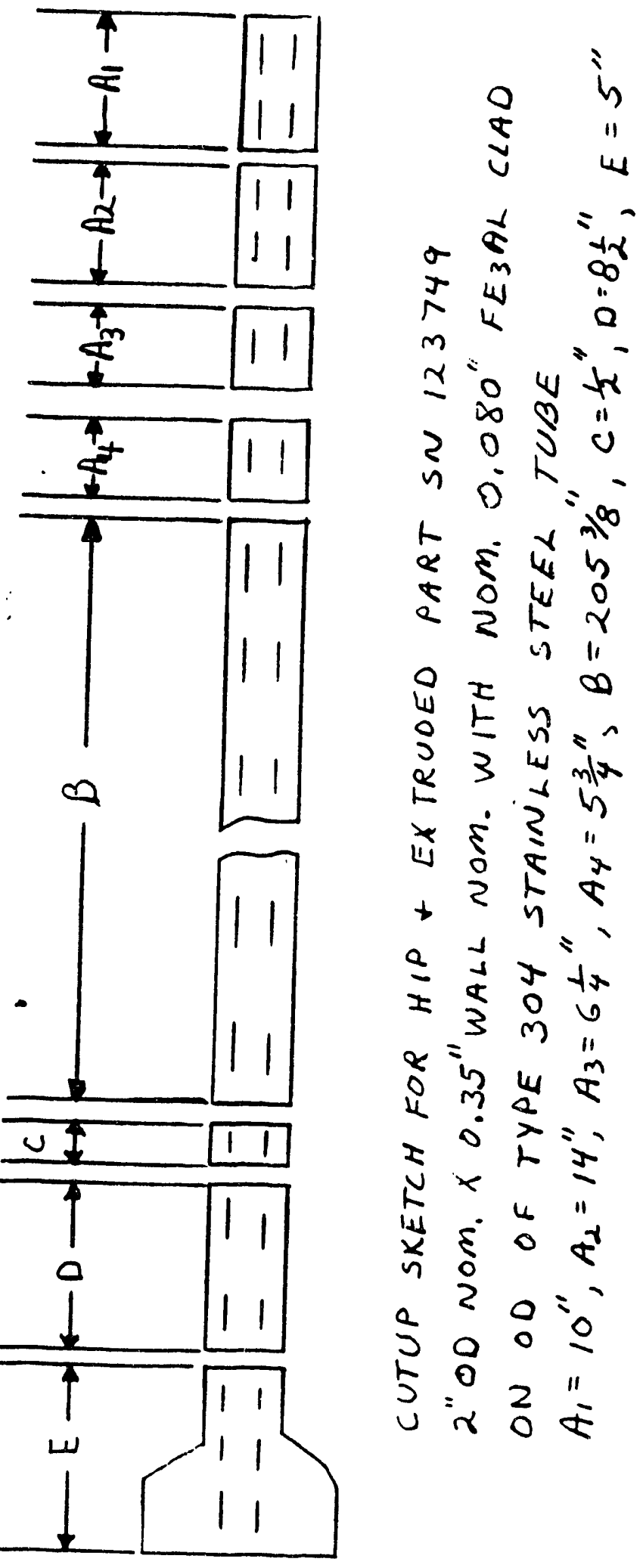
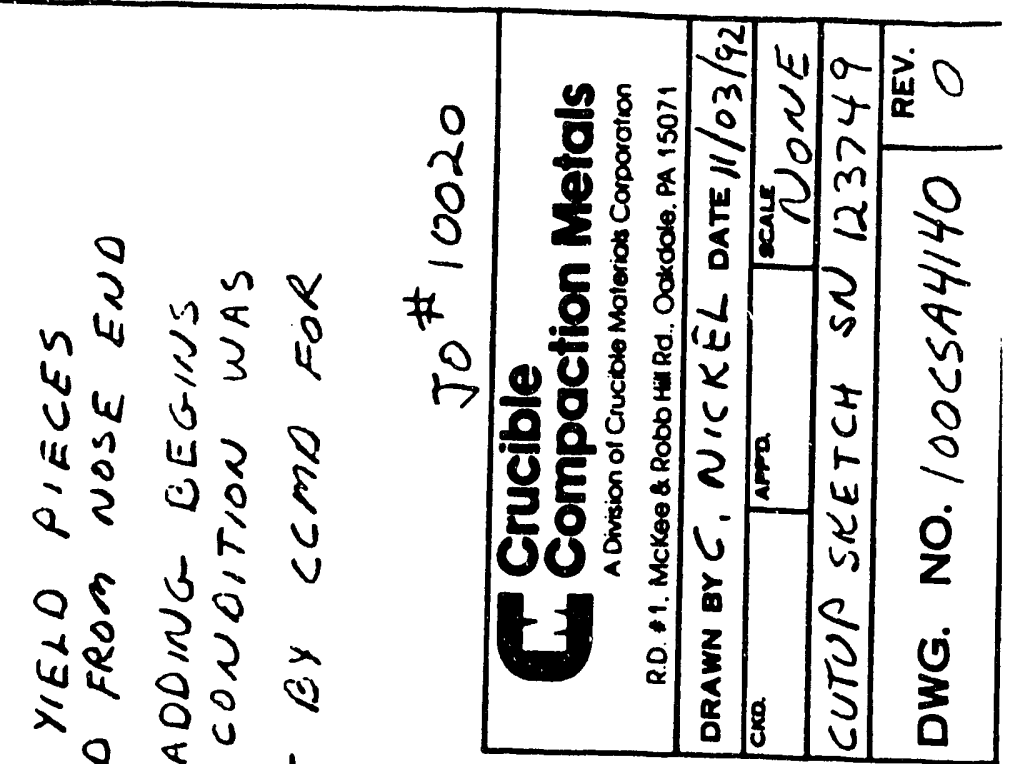

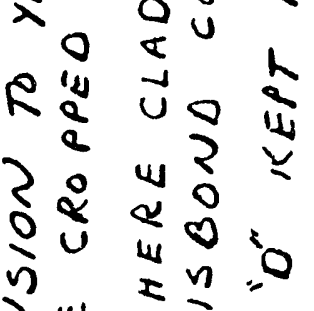

$\begin{array}{llll}2 & 3 & 2 & m\end{array}$

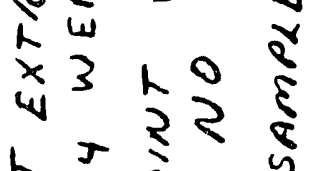

$2 \pi$
2
5

$4<0_{0}$.

$0 \dot{\tau} \psi 0$ w

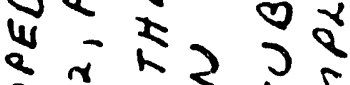

\& $2<>05$

unv vv

w 5 ह

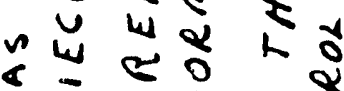

$3 a \leqslant \leqslant$

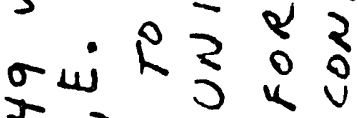

No 4

m $\infty$ m 0 र

$4 \cup 5 \infty 5=$

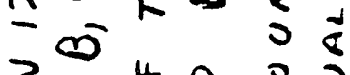

旅

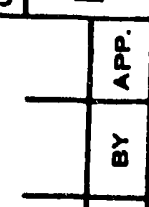



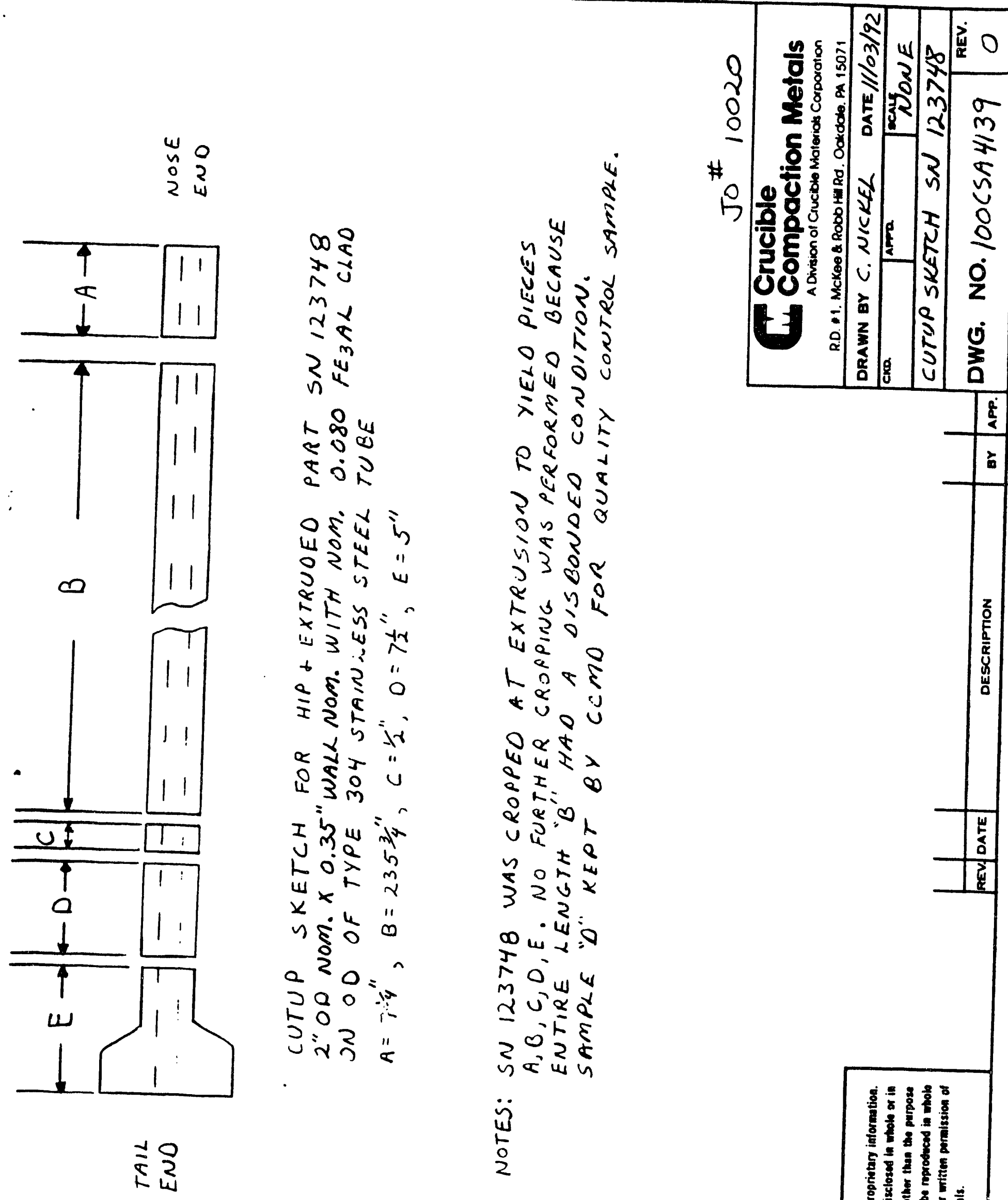
December 1, 1992

Dr. R. W. Swindeman

Martin Marietta Energy Systems, Inc.

Oak Ridge National Laboratory

Bldg. 4500 South, M56155

Bethel Valley Road

Oak Ridge, TN 37831-6155

Ref.:

"Evaluation of the Fabricability of Advanced Iron Aluminide-Clad Austenitic Stainless Stoel Tubing"

MMES: 72X-SB775-C

B\&W: CRD 1207

Dear Bob:

I am sending to you by express mail a five-foot length of iron aluminide-clad 304 stainless steel tubing that was successfully produced under the referenced contract. This material, which was extruded at $2000^{\circ} \mathrm{F}$, has a 2-inch O.D. with a nominal 3/8-inch wall that includes a nominal 1/10-inch thick Fegl clad layer. The five-foot section is representative of the entire eighteen foot clad tube from which it was taken. The remaining material, in addition to another eighteen-foot clad tube (extruded at $2200^{\circ} \mathrm{F}$ ), is currently being evaluated in accordance with the program workscope. I'll continue to keep you informed as our work progresses.

Sincerely,

THE BABCOCK \& WILCOX COMPANY

Research and Development Division

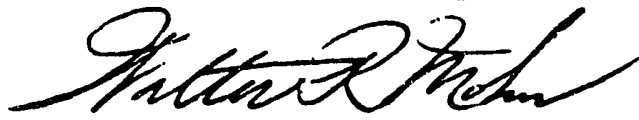

W. R. Mohn

Metallurgy \& Manufacturing

Technology Section

bp

œ: NCCole - ORNL

RAGleixner - ARC

RWHaggard - CRD

DFLaCount - ARC

MJTopolski - ARC 
Dr. R.W. Swindeman

Martin Marietta Energy Systems, Inc.

Oak Ridge National Laboratory

Bldg. 4500 South, M56155

Bethel Valley Road

Oak Ridge, TN 37831-6155

Ref: MMES: 72X-SB775-C

B\&W: CRD 1207

Dear Bob:

In accordance with your request, I am sending you by express mail three pieces of advanced austenitic stainless steel tubing produced under the referenced contract. These include a 5-foot length of iron aluminide-clad 304 stainless steel tubing and two 6-foot lengths of $\mathrm{m} 800 \mathrm{H}$ stainless steel tubing (Heat No. V988-1). Please contact me if I may provide further assistance.

Sincerely,

THE BABCOCK \& WILCOX COMPANY

Research and Development Division

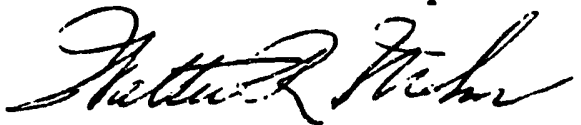

Walter R. Mohn

Metallurgy \& Manufacturing Technology

c: NCCole - ORNL

RAGleixner - ARC

RWHaggard - CRD

DFLaCount - ARC

MJTopolski - ARC 


\section{Appendix F}

Procedure For Etching Of

Iron Aluminide Clad 304 Stainless Steel 


\section{ETCH PROCEDURE}

- Prepare Solution: $50 \mathrm{~g} \mathrm{NaOH}+100 \mathrm{ml}$ Water.

-Immerse5 minutesin NaOH Solution@160F.

- Immerse in Chromic Etchant and apply 6 Volts DC Potential for 30 seconds, Then Check Microscopically; As required, Apply for an additional 10 Seconds (or More). 


\section{Appendix G}

Distribution List 
AIR PRODUCTS AND CHEMICALS

P.O. Box 538

Allentown, PA 18105

S. W. Dean

S. C. Weiner

ALBERTA RESEARCH COUNCIL

Oil Sands Research Department

P.O. Box 8330, Postal Station F

Edmonton, Alberta

Canada T6H5X2

L. G. S. Gray

ALLISON GAS TURBINE DIVISION

P.O. Box 420

Indianapolis, IN 46206-0420

P. Khandelwal (Speed Code W-5)

R. A. Wenglarz (Speed Code W-16)

AMAX R\&D CENTER

5950 McIntyre Street

Golden, CO 80403

T. B. Cox

\author{
ARGONNE NATIONAL LABORATORY \\ 9700 S. Cass Avenue \\ Argonne, IL 60439 \\ W. A. Ellingson \\ K. Natesan
}

ARGONNE NATIONAL LABORATORY-WEST

P.O. Box 2528

Idaho Falls, ID 83403-2528

S. P. Henslee

\section{AVCO RESEARCH LABORATORY}

2385 Revere Beach Parkway

Everett, MA 02149

R. J. Pollina

BABCOCK \& WILCOX

1562 Beeson St.

Alliance, OH 44601

T. I. Johnson

BABCOCK \& WILCOX

Domestic Fossil Operations

20 South Van Buren Avenue

Barberton, $\mathrm{OH} 44023$

M. Gold

BATTELLE-COLUMBUS LABORATORIES

505 King Avenue

Columbus, $\mathrm{OH} 43201$

I. G. Wright
BETHLEHEM STEEL CORPORATION

Homer Research Laboratory

Bethlehem, PA 18016

B. L. Bramfitt

J. M. Chilton

BRITISH COAL CORPORATION

Coal Research Establishment

Stoke Orchard, Cheltenham

Glochester, England GL52 4RZ

M. Arnold

C. Bower

A. Twigg

BRITISH GAS CORPORATION

Westfield Development Centre

Cardenden, Fife

Scotland KY5OHP

J. E. Scott

CANADA CENTER FOR MINERAL \& ENERGY TECHNOLOGY

568 Booth Street

Ottawa, Ontario

Canada K1A OG1

R. Winston Revie

Mahi Sahoo

COLORADO SCHOOL OF MINES

Department of Metallurgical Engineering

Golden, CO 80401

G. R. Edwards

EC TECHNOLOGIES INC.

3614 Highpoint Drive

San Antonio, TX 78217

D. J. Kenton

ELECTRIC POWER RESEARCH INSTITUTE

P.O. Box 10412

3412 Hillview Avenue

Palo Alto, CA 94303

W. T. Bakker

J. Stringer

H. Wolk

EUROPEAN COMMUNITIES JOINT RESEARCH CENTRE

Petten Establishment

P.O. Box 2

1755 ZG Petten

The Netherlands

M. Van de Voorde 
EOSTER WHEELER DEVELOPMENT CORPORATION

Materials Technology Department

John Blizard Research Center

12 Peach Tree Hill Road

Livingston, NJ07039

J. L. Blough

IDAHO NATIONAL EN SIIYEERING

LABORATORY

P.O. Box 1625

Haho Falls, ID 83415

D W. Keefer

LAWRENCE LIVERMORE LABORATUIRY

P.O. Box 808, L-325

Livermore, CA 94550

W. A. Steele

NATIONAL INSTITUTE OF STANDAI.DS AND TECHNOIUUGY

Materials Building

Gaithersburg, MD 20899

L. K. Ivc:

NATIONAL MATERIALS ADVISORY BOARD

National Research Council

2101 Constitution Avenue

Wasıington, DC 20418

K. M. Zwilsky

NEW ENERGY AND INDUSTRIAL TECHNOLOGY DEVELOPMENT ORGANIZATION

Sunshine 60 Bldg.

P.O. Box 1151, 1-1

Higasiti-lkebukuro 3-chrome

Toshima-Ku, Tokyo, 170

Japan

H. Necita

S. Ueda

OAK RIDGE NATIONAL LABORATOR'Y

P.O. Box 2008

Oak Ridge, TN 37831

P. T. Carlson

N. C. Cole

R. R. Judkins

R. A. Lawsion (8 copies)

R. W. Swindeman

P. T. Thornton

\section{RESEARCH TRIANGLE INSTITUTE}

P.O. Box 12194

Research Triangle Park, NC 27709

T. W. Sigmon
SHELL DEVELOPMENT COMPANY

P. O. Box 1380

Houston, TX 77251-1380

L. W. R. Dicks

THE JOHNS HOPKINS UNIVERSITY

Materials Science \& Engineering

Maryland Hall

Baltimore, MD 21218

R. E. Green, Jr.

THE MATERIALS PROPERTIES COUNCIL, INC.

United Engineering Center

345 E. Forty-Seventh Street

New York, NY 10017

M. Prager

THE TORRINGTON COMPANY

Advanced Technology Center

59 Field Street

Torrington, CT 06790

W. J. Chmura

UNION CARBIDE CORPORATION

Linde Division

P.O. Box 44

175 East Park Drive

Tonawanda, NY 14151-0044

Harry Cheung

UNIVERSITY OF TENNIESSEE AT KNOXVILLE

Materials Science and Engineering Department

Knoxville, TN 37996

R. A. Buchanan

C. D. Lundin

UNIVERSITY OF TENNESSEE SPACE. INSTITUTE

Tullahoma, TN 37388

J. W. Muehlhauser

UNIVERSITY OF WASHINGTON

Department of Materials Science and Engineering

101 Wilson, FB-10

Seattle, WA 98195

T. G. Stoebe

WESTERN RESEARCH INSTITUTE

365 N. 9th Street

P.O. Box 3395

University Station

Laramie, WY 82071

V. K. Sethi 
WESTINGHOUSE HANFORD COMPANY P.O. Box 1970,W/A-65

Richland, WA 99352

R. N. Johnson

DOE

IDAHO OPERATIONS OFFICE

P. O. Box 1625

Idaho Falls, ID 83415

R. B. Loop

DOE

DOE OAK RIDGE OPERATIONS

P. O. Box 2001

Oak Ridge, TN 37831

Assistant Manager for Energy Research and Development

DOE

DOE OAK RIDGE OPERATIONS

P. O. Box 2008

Building 4500N, MS 6269

Oak Ridge, TN 37831

E. E. Hoffman

DOE

OFFICE OF BASIC ENERGY SCIENCES

Materials Sciences Division

ER-131 GTN

Washington, DC 20545

J. B. Darby

\section{DOE}

OFFICE OF ENERGY EFFICIENCY AND RENEWABLE ENERGY

CE-12 Forrestal Building

Washington, DC 20545

J. J. Eberhardt

DOE

OFGICE OF FOSSIL ENERGY

Washington, DC 20545

J. P. Carr (FE-14) GTN
DOE

MORGANTOWN ENERGY TECHNOLOGY CENTER

P.O. Box 880

Morgantown, WV 26505

R. A. Bajura

R. C. Bedick

D. C. Cicero

F. W. Crouse, Jr.

N. T. Holcombe

W. J. Huber

M. J. Mayfield

J. E. Notestein

J. S. Wilson

DOE

PITTSBURGH ENERGY TECHNOLOGY CENTER

P.O. Box 10940

Pittsburgh, PA 15236

A. L. Baldwin

G. V. McGurl

R. Santore

T. M. Torkos

DOE

OFFICE OF SCIENTIFIC AND TECHNICAI INFORMATION

P. O. Box 62

Oak Ridge, TN 37831

For distribution by microfiche as shown in DOE/TIC4500, Distribution Category:

UC-114 (Coal Based Materials and Components) 

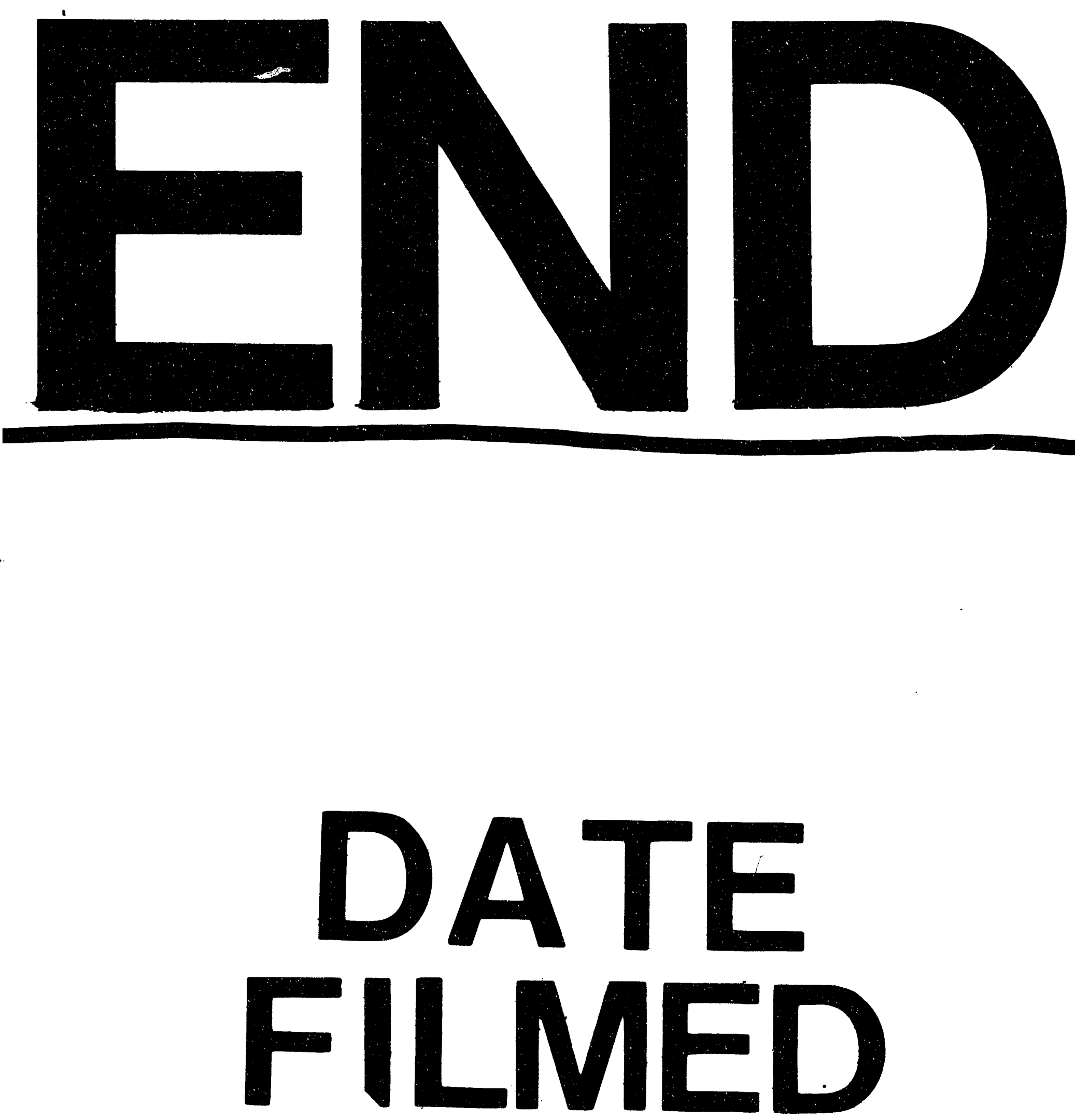

$11 / 16 \mid 93$ 
